\title{
Electromobility and Its Effects on Automotive Workshops
}

\author{
Helmut Ropin*, Robert Supan
}

\begin{abstract}
Due to stricter $\mathrm{CO}_{2}$ emission limits, new competitors and imminent driving bans, electromobility has registered high growth rates in Austria. The rising number of electric vehicles not only has an impact on automobile production and its suppliers, but also on the after-sales business with the focus on the repair market. In order to meet these requirements, automotive workshops have to redesign and realign their organizational structures and they have to compensate their decreasing service-revenues. Electromobility requires additional qualification and training of employees and the expansion of technical equipment. Small workshops especially are facing this challenge. In order to obtain an answer to the current status of service companies, a qualitative study was carried out and the status was determined based on expert interviews. Recommendations for action can be derived as a result and it can be shown that there is a big difference between the independent and authorised workshops.
\end{abstract}

Keywords: after-sales business; automotive after-sales; automotive workshops; electromobility

\section{INTRODUCTION}

The worldwide rethinking of drive concepts in the automotive industry is not only leading to a change in manufacturers and the supply industry, but also car service companies, the spare parts business, workshop service and business models must be adapted to these effects [1]. According to Fraunhofer IOA [2], in Germany, 100,000 jobs will be at risk by 2030 as a result of electromobility, compared to only 25,000 newly created jobs. The biggest driver for this change is currently the $\mathrm{CO}_{2}$ emission limit value, which actually stands at $95 \mathrm{~g} \mathrm{CO}_{2} / \mathrm{km}$ as a fleet value for new vehicles [3]. In view of historical developments, automobiles have become more and more complex on a technical scale in the recent decades and maintenance has become more expensive as a result. With the entry of electromobility, complexity is now being reduced again and this means that car workshops will feel a profound impact on value creation. For example, the classic oil change, the replacement of timing belts and clutches will no longer be necessary. However, the combined use of a conventional and electric drive train leads to new challenges in workshop processes [3]. This paper gives an overview of the common drive concepts and the after-sales business in the automotive industry. Furthermore, the effects of electromobility on Austrian car service companies are elaborated in detail and are verified by a qualitative study. The results show the necessary changes in occupational safety, human resources, workshop processes and investments. Additionally, recommendations for Austrian motor vehicle service companies are derived. The empirical investigation in this paper is based on a qualitative study by using guided interviews. This form offers a flexible application and the openness of the approach can generate previously unknown information [4].

\section{ELECTRIFIED DRIVE CONCEPTS}

The rising growth rates in worldwide sales of electric vehicles show a continuous trend towards diversification in drive concepts. In 2019, the worldwide stock of electric vehicles was around 7.9 million, growing by more than 2.2 million compared to the previous year [5]. Measured against the total vehicle population of around 1.13 billion vehicles excluding commercial vehicles, this corresponds to a share of around $0.7 \%$ [6]. A historical review at the beginning of the $20^{\text {th }}$ century shows that $38 \%$ of automobiles in the USA were already being driven electrically at that time [7]. The first hybrid vehicle in the world was the Lohner-Porsche from 1900, which achieved an electric range of $50 \mathrm{~km}$ and a speed of $50 \mathrm{~km} / \mathrm{h}$ with its $410 \mathrm{~kg}$ battery. The belief in electromobility lasted until 1912, when the electric starter for internal combustion engines was invented and thus the electric car lost massively in importance. However, the electrification of the powertrain continued to occupy automobile manufacturers - the final breakthrough, however, came in 2006 with the Roadster model from Tesla, which could drive several hundred kilometres and marked the beginning of a new era in electromobility [8]. In addition to the familiar combustion engines, today's drive concepts often offer purely electric drives as well as various combinations of combustion engine and electric motor, the so-called hybrids. Additionally, there are also Range Extended Vehicles, which drive purely electrically, but have a combustion engine on board to extend the range $[9,10]$.

\subsection{Battery Electric Vehicle (BEV)}

These vehicles have one or more electric motors, power electronics and a traction battery. A combustion engine is not used. The main advantage of the BEV is the high efficiency of the components, which is between 87 and $98 \%$. Three-phase motors are almost exclusively used, since they have a very high efficiency $[11,12]$.

\subsection{Hybrid Electric Vehicle (HEV)}

A HEV has two different energy converters and accumulators, whereby the energy converters can convert mechanical energy directly into propulsion, or charge the 
generated electrical energy into the energy accumulator. The primary goal of this concept is to increase the range of the vehicle. Disadvantages include the loss of installation space and the more complex design. HEVs are classified according to the so-called degree of hybridization [9]. A distinction is made here between Microhybrid, Mildhybrid, Fullhybrid and Plug-In Hybrid Electric Vehicle (PHEV).

\subsection{Range Extended Electric Vehicle (REEV)}

REEV is powered exclusively by an electric motor and the battery is charged either by an external charging point or by an internal combustion engine which acts as a generator and recharges the traction battery as required. The internal combustion engine can be operated in its optimum working range, although the efficiency of the overall system is lower. This is called a serial hybrid drive [3].

\subsection{Fuel Cell Vehicle (FCV)}

Similar to the REEV, the Fuel Cell Vehicle also uses only the electric motor for propulsion. Here, however, the fuel cell with a hydrogen tank is used, which drives the electric motor directly or can charge the traction battery [13].

The following figure shows a summary of all forms of powertrain electrification.

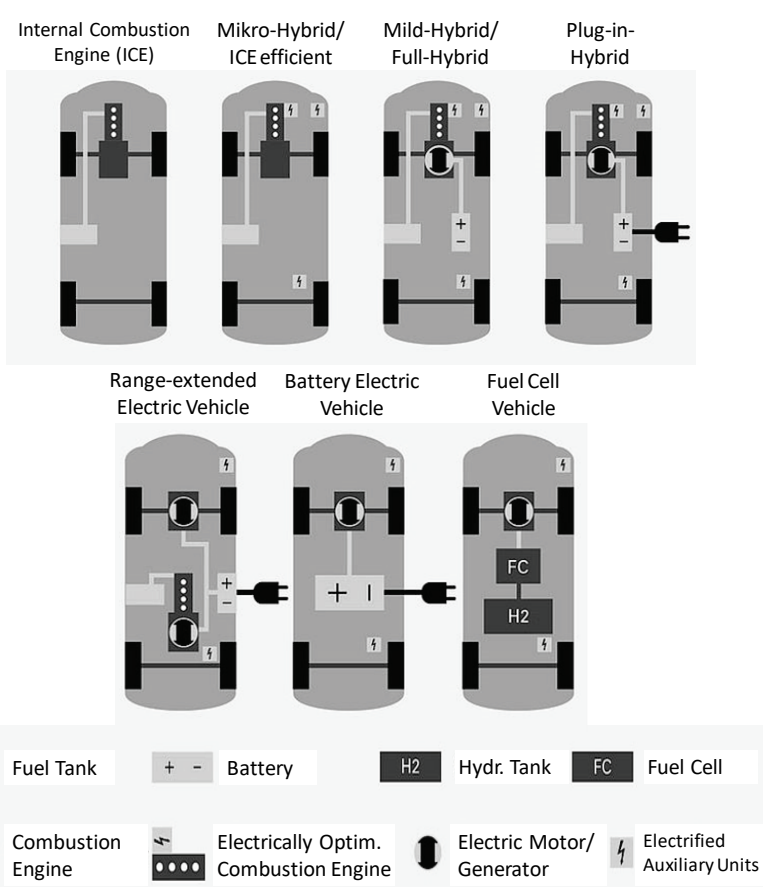

Figure 1 Characteristics of the electrification of the drive train [14]

\section{AFTER SALES IN THE AUTOMOTIVE INDUSTRY}

The automotive industry in Austria has around 370,000 employees in total and, with 14.1 billion euros in foreign sales, it is the second most important export sector. In addition to the production of motor vehicles, this also includes marketing, maintenance and disposal $[15,16]$. The term Maintenance is often used as an overall definition of after-sales service, which can include various services after the purchase of products [17]. In the automotive industry, after-sales begins as soon as the sale of a vehicle is completed. The after-sales market is basically divided into parts business and service and repair business [18]. Fig. 2 shows the various stages of the value chain and the market participants:

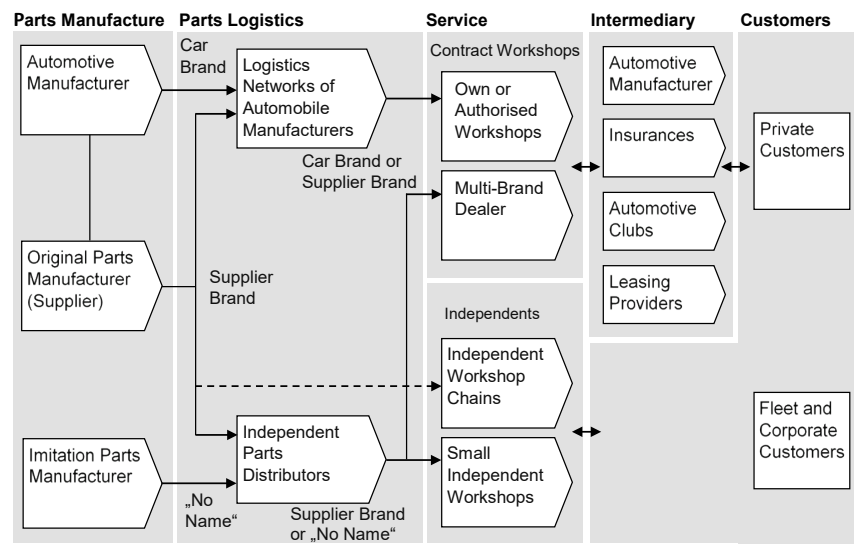

Figure 2 Value chain and market participants in the automotive after-sales [19]

In parts manufacture, the original equipment manufacturers supply their products with the appropriate logo either to car manufacturers or to independent parts distributors. It is also possible for parts manufacturers to supply parts directly to the workshop chains. Imitation parts are brought onto the market via independent parts dealers. In the second stage of parts logistics, the logistics networks of the automobile manufacturers and independent parts dealers operate, and they primarily supply independent workshops. The third stage comprises the actual service business, whereby a distinction is made here between the contractbased and independent vehicle service operations. The fourth level comprises intermediaries who mediate between the customers and car repair shops in order to push through low prices [19]. The after-sales business has a relatively low share of $11 \%$ of total sales in the automotive industry, but it is one of the most profitable sectors with $38 \%$ profit. By comparison, new car sales have a $41 \%$ share of sales with only $4 \%$ profit. One of the most profitable sectors is financial services with a $42 \%$ profit [20]. The after-sales business is an important economic factor for the original equipment manufacturer (OEM) and the independent aftermarket (IAM). Finally, price-conscious customers often find a better offer for services and switch to them after the guarantee period.

In Austria, approximately 12,800 companies are operating in the automotive sector. 5,400 of them are car repair shops and they generate a turnover of 4.8 billion euros [21]. The car repair shops can be assigned to the service and repair market, which is primarily divided into two groups [22]:

- Independent workshops: The focus is usually on the maintenance and repair of older vehicles and these are not dependent on manufacturers and can move freely on 
the market. Another form are workshop chains that are identical nationwide.

- Authorised workshops: These companies are contractually bound to one or more car manufacturers and are often active in the new and used car trade. In addition to these sales partners, there are also OEMowned branches that the car manufacturer maintains.

The brand-linked service companies are often confronted with the fact that vehicle owners switch to independent repairers for cost reasons after the vehicles have been in service for more than six years and thus lose important sales [23]. According to Dispan, the service business of the future will be characterized by five trends [22]:

- Longer maintenance intervals and higher vehicle quality lead to lower market volume in the service business.

- The higher inventory of older vehicles leads to a higher work volume.

- Flexibility, price, support and convenience are becoming more and more important to customers.

- Technological change in the form of electromobility and digitalization are relevant for service operations.

- Due to the intensified competitive situation, cut-throat competition is emerging.

\section{IMPACT OF ELECTROMOBILITY ON AUTOMOTIVE WORKSHOPS}

The amount of electrified vehicles is steadily rising in Austria. The number of new registrations of BEV rose by $37 \%$ from 2018 to 2019, while the number of vehicle registrations in Austria fell by $2.8 \%$ in the same period [24, 25]. The high increases will not only change the upstream processes of vehicle production, but also all subsequent value-adding processes, the downstream, will have to adapt to future conditions [26]. In this context, automotive workshops are already under high cost and sales pressure. Increasingly sophisticated developments and production methods are making repair cycles longer, which reduces the need for spare parts [27]. In the following section, the effects of electromobility on the different areas and processes of an automotive workshop are presented.

\subsection{Work Safety and Qualification of Employees}

Hybrids and Battery Electric Vehicles are operating with voltages of up to $800 \mathrm{~V}$ [28]. These can cause serious injuries, such as ventricular fibrillation or burns, if operated improperly. To minimize these risks when working on electric vehicles, proper protective equipment, such as insulated tools or safety gloves, must be provided. Highvoltage technology thus distinguishes the service of electrified vehicles from those with a conventional drive concept. To be able to work on electrified vehicles with highvoltage technology, it is necessary to train and raise awareness among employees. The qualification is divided into three levels $\mathrm{HV}-1, \mathrm{HV}-2$ and $\mathrm{HV}-3$ ( $\mathrm{HV}=\mathrm{High}$ Voltage). HV-1 covers all non-electronic activities. HV-2 includes all activities of HV-1 and additionally, the voltage isolation, the determination of the absence of voltage, when work on the high voltage system can be carried out. The third level HV-3 is based on HV-2. This authorises the employee to work on vehicles that are not $\mathrm{HV}$-intrinsically safe and on high-voltage energy storage systems $[29,30]$.

\subsection{Technical Equipment}

To meet the requirements of high-voltage systems, investments must be made in the technical equipment [31]. The study of the State Agency for Electromobility and Fuel Cell Technology Baden-Württemberg "Development of Employment in After Sales" developed two concepts for the investments for car service companies in Germany. The basic variant focuses on one workplace which carries out maintenance and repair work, and the costs for this are $10,100 €$. The second concept comprises a competence centre consisting of four workplaces, equipped with the necessary technical equipment for electromobility. The costs for the competence centre are $48.060 €$ [32].

\subsection{Effects on the Workshop Process}

Workshop processes are often standardized in successful companies. This minimizes uncoordinated processes, time losses and increases the added value [33]. Services for electric vehicles are also changing the structure of classic workshop processes. For example, a specifically trained specialist must be scheduled in the appointment preparation process. New types of complaints and claims must be taken into account, such as the charging or range of the vehicle. The new drive concept also fundamentally changes the service and repair activities [32].

\subsection{Changes in Repair and Maintenance Services}

The specific characteristics of vehicles with electrified drive trains are changing the economic considerations of maintenance and repair. Vehicles have certain components and fluids that require regular maintenance. The intervals are determined by the OEM. However, vehicles with combustion engines have components that require much more maintenance [34]. The following table compares the various drive concepts regarding the maintenance and repair measures.

Table 1 Maintenance and repair of various drive concepts [32]

\begin{tabular}{|l|c|c|c|c|}
\hline & ICE & Hybrid & REEV & BEV \\
\hline Oil change & $\checkmark$ & $\checkmark$ & $\checkmark$ & - \\
\hline Exchange coolant & $\checkmark$ & $\checkmark$ & $\checkmark$ & - \\
\hline Exchange spark plug & $\checkmark$ & $\checkmark$ & $\checkmark$ & - \\
\hline Exchange fuel filter & $\checkmark$ & $\checkmark$ & $\checkmark$ & - \\
\hline Exchange brake fluid & $\checkmark$ & $\checkmark$ & $\checkmark$ & $\checkmark$ \\
\hline Check power electronics & - & $\checkmark$ & $\checkmark$ & $\checkmark$ \\
\hline Additional coolant & - & $\checkmark$ & $\checkmark$ & $\checkmark$ \\
\hline Brake system & $\checkmark$ & reduced & reduced & reduced \\
\hline Exhaust system & $\checkmark$ & reduced & reduced & reduced \\
\hline Clutch & $\checkmark$ & reduced & - & - \\
\hline
\end{tabular}

As shown in Tab. 1, the maintenance and repair effort of the electric vehicle is significantly lower compared to the ICE. In contrast, the operation of a hybrid vehicle is associated with a higher effort. 


\subsection{Turnover and Employment}

As shown in Tab. 1, electrified vehicle concepts require considerably less maintenance and repair work. The Deloitte study "The Future of Automotive Sales \& Aftersales" concludes that an after-sales business could be threatened with a $55 \%$ decline in sales by 2035 . As a scenario, Deloitte assumed that $40 \%$ of all new car sales in 2035 will have an alternative drive concept (BEV, Hybrid, FCV). If only the area of maintenance and service is considered, a decline of $84 \%$ is assumed [35].

\section{RESEARCH METHODOLOGY}

In order to investigate the current status regarding the effects of electromobility and the future development of Austrian car service companies and to compare it with the current state of literature, this paper is based on a qualitative research method. The following research questions are examined on the basis of the empirical study:

1) Which requirements and challenges will be faced by skilled workers and their companies as electromobility moves forward?

2) What investments do car service companies have to make in order to service and repair electrified vehicles?

3) Are the changes in the workshop process a relevant problem?

4) How large will the decline in sales and workload be if electromobility continues to grow at such high rates?

\subsection{Guideline Interviews}

An empirical study based on a quantitative method using semi-standardised guideline interviews was selected as the research methodology. Compared to the quantitative approach, this methodology offers a much more open and flexible approach to data collection. It is possible to understand and interpret correlations. The often spoken words such as interviews, texts, written documents and observed behaviour are examined with the aim of deriving theoretical statements from the collected data [36]. Guided interviews are standardised and the same one is used for each interview to allow comparability. The interview is structured, although the order of the questions may vary. Additional questions can be asked. The personal interview was chosen as a variant of the communication form [37]. The interview guidelines were designed in an iterative process, whereby the research questions mentioned above served as a basis and three blocks of questions were derived: general questions ( $n$ $=3)$, specific questions $(n=7)$, basic data query $(n=7)$.

\subsection{Expert Selection and Participant Structure}

The selection of experts or the appropriate group of persons has a significant influence on the success of the data collection. The experts selected for the work in this study are persons in the leading positions in the service sector of automotive workshops. In the final analysis, company owners, plant managers and workshop managers were interviewed. The survey of test persons was always conducted on site and it included ten companies with ten participants. The participant structure shows that the number of employees in workshop operations is between 2 and 70 persons and thus represents a good cross-section. Both the independent workshops and authorised workshops of various manufacturers were surveyed.

\section{RESULTS}

In the following section, the results of the qualitative study are presented and are aggregated in four categories.

- Work safety and qualification of employees,

- Experience and future of drive concepts,

- Workshop process and effects on turnover and workload,

- Investments.

\subsection{Work safety and qualification of employees}

In practice, the experts consider the newly emerging sources of danger to be especially problematic. The high voltages of high-voltage components can be life-threatening if handled incorrectly. It is therefore necessary to raise the employees' awareness of this issue. Furthermore, not all employees are yet willing to accept electromobility. However, the problem of acceptance is not only based on electromobility, but also on the general change that the profession of a car technician is subject to. Work on electronic components is constantly increasing. Only two out of ten experts were able to ascertain a high level of willingness for further training in the field of electromobility in their companies.

\subsection{Experience and the Future of Drive Concepts}

The majority of experts have already gained experience with electric vehicles. $40 \%$ have already considered the purchase of an electric vehicle, but none of them has realized this plan yet, mainly due to the price and range. $70 \%$ of the experts assume that petrol or diesel vehicles will continue to lead the registration statistics in the next 5-10 years. However, diesel will lose market share. There is disagreement about hybrid technology. 30\% of the experts are convinced that the hybrid will be at the top of the list of new registrations due to its benefits of private use for company vehicles and fleet consumption. In contrast, companies with a high number of sales of BEV and hybrids have experienced that the hybrid is less in demand than the BEV. Other drive concepts were not considered as relevant for the next years. One expert sees electromobility only as an interim solution to meet the fleet consumption of the European Union. Moreover, $80 \%$ of the respondents do not consider electromobility to be relevant in the next five years for automotive workshops, especially in the rural areas. Although the experts expect that the percentage of BEV and hybrid vehicles will increase, hybrids will be able to compensate for the losses of BEV. 


\subsection{Workshop Process and the Effects on Turnover and Workload}

$80 \%$ of the companies have already gained experience with electromobility. The provided services ranged from service work to repairs on the electric engine and battery. The effects on the workshop process mentioned in 4.3 could be partially verified. Electromobility has no noticeable influence on regular service and maintenance work. Only the sub-process of vehicle return changes, as the workshops return the vehicles to the customer charged. However, repairs of electrified vehicles are seen as problematic. For example, areas around the vehicle being repaired must be cordoned off and batteries can only be opened and repaired in a separate room. The problem of accident vehicles has also been explained, separate quarantine areas outside are necessary and a HV-2 or HV-3 trained person must first check the vehicle and clarify how to proceed further. The disposal process also differs. External service providers must be requested to dispose battery components, as there is an increased risk of fire.

Although it could be verified that the service process will not undergo any relevant changes as a result of electromobility, this does not apply to the workload and volume of sales. A hypothetical example was created in which a quarter of all vehicles in Austria are purely electrically powered. Based on this scenario, the question was which of the regularly occurring service and maintenance work would be most difficult to compensate for. The regular oil and filter change were named first by all the experts. Although the turnover generated with the vehicle's operating resources is relatively low, the profit margin is very high. The exhaust- and brake system were also mentioned by the majority of the experts. The lower service costs are also a decisive factor, see below Tab. 2 on different service costs based on the information provided by one company.

Table 2 Comparison service costs for BEV and ICE

\begin{tabular}{|l|c|c|}
\hline & Service costs 3 years $(€)$ & Service costs 4 years $(€)$ \\
\hline ICE & 1500 & 1900 \\
\hline BEV & 600 & 800 \\
\hline Sales decline & 900 & 1100 \\
\hline
\end{tabular}

The data from Tab. 2 shows that in this company, the turnover for a battery electric vehicle service is between 300 and $275 €$ lower. The expert summed up the topic with the words "In the case of the electric vehicle, components are checked and in the case of the combustion engine, they are replaced". Furthermore, $40 \%$ of the experts estimated a decrease in the workload and sales volume at about $20-25 \%$, while $30 \%$ believe that electromobility will only have a minor impact on the workload and sales volume. New services, such as battery repair, will compensate for any reductions due to oil changes that are no longer required. Legislation and OEMs were also mentioned. It is assumed that additional regular services will be implemented for BEV. The remaining $30 \%$ of the experts abstained or estimated the decrease to be around $10-15 \%$.

\subsection{Investments}

This area of investigation is intended to provide information on various investments. The following figure provides an overview of the investments made. The independent automotive workshops are provided with a frame.



As shown in Fig. 3, independent automotive workshops have neither made nor plan to make any investments in the future, while all the authorised workshops that were surveyed have already invested in electromobility. The investment volume starts at $15,000 €$ and ends at $450,000 €$. This large difference can partly be attributed to the size of workshops or because construction measures have been taken. The largest investment volume is made by the largest company and the high amount can be explained by the high costs of the quick charging stations. Approximately 160,000-200,000 € are spent on them. Other reasons can also be attributed to the respective contract partner. Depending on the OEM, different regulations apply to the workshops. The prices for special tools or training can also differ. If no construction measures are taken, charging stations and tools are the largest items, followed by trainings. In general, the investments of authorised workshops strongly depend on the requirements of the car manufacturer.

\section{KEY RESULTS}

At the beginning of this paper, it was stated that the automotive industry is facing an increasing change due to the new mobility requirements of the society, digitalization and stricter $\mathrm{CO}_{2}$ emission limits. Without electrified vehicles, $\mathrm{CO}_{2}$ emission limits cannot be fulfilled. After conducting expert interviews, it became clear that in practice, electromobility will have different effects on automotive workshops. At present, electromobility has no relevant impact on independent workshops. For authorized workshops, the contractual partners, i.e. the car manufacturers, set the course. All the authorized workshops that were surveyed have already had experience with electrified vehicles. The issue of work safety is particularly noteworthy. Due to the invisible danger of high voltages, it is particularly important to raise awareness among employees. It was also found that electromobility, depending on whether 
service or repair work is to be carried out, requires high investments, which are difficult to handle, especially for smaller companies. Regarding the workshop process, a distinction must be made between service and repair work. Although the service work on a BEV has no relevant effect on the workshop process, repair work, especially on damaged vehicles, is a problem. Here, workshops have not yet been able to gain sufficient experience. If electromobility becomes widely accepted, the majority of experts estimate that there will be a significant decline in the workload and sales volumes. This also coincides with the studies described in this paper. However, the majority of experts also consider that electromobility will be irrelevant for automotive workshop companies in the next five years. The empirical study shows that electromobility will ultimately have a major impact on automotive workshops. However, one factor is decisive here, namely the market penetration of electric vehicles.

\section{RECOMMENDATION FOR ACTION}

In order to be able to give recommendations for the action of automotive workshops concerning electromobility, it is important to distinguish between independent and authorised workshops, as they address different customer groups and authorised workshops are tied to manufacturers' requirements.

In the authors' view, independent workshops do not have to invest heavily in electromobility in the next five years. However, it is important not to ignore electromobility and to closely follow market changes and growth. Moreover, electromobility should be taken into account if construction measures are planned. The research results from the scientific work and the empirical study show that independent workshops are very rarely servicing and repairing new cars and that this business is responsible for the authorised workshops. Since electric and hybrid vehicles are still a niche market, the percentage of used vehicles on the market with electrified drive concepts is low, and so is customer demand. High investments for structural and mechanical adaptation (e.g. a separate room for battery repair, extra wide lifting platforms) make independent workshops still hesitant. In order not to overlook the right time, it is advisable on the one hand, and operationally, to carry out an ongoing screening of the publicly available registration statistics and the private used car market; with always the same consistent query on the hybrid and BEV on the same used car portals. Should the figures move up significantly, a business decision on the "entry" into the electrical repair market should be made regarding the necessary investments. On the other hand, and also strategically, the $\mathrm{CO}_{2}$ emission limit set by the EU can also be observed, as this is an indicator of the extent to which car manufacturers must adapt to avoid penalties.

Authorised workshops are affected by electromobility earlier than independent workshops, as almost all car manufacturers offer hybrids and BEVs. In general, authorised workshops are very much dependent on the decisions of their respective car manufacturers. Workshop design or required personnel and tools are only a few examples of the different specifications. Accordingly, electromobility is largely determined by the OEM. However, in order to accelerate the amortization of the investments made in electromobility, it is beneficial to keep an eye on the new mobility concepts. For example, newly emerging CarSharing platforms offer the possibility of receiving service and repair orders for the vehicle fleet, and such platforms often have a comparatively high share of BEV.

\section{Notice}

The paper will be presented at MOTSP 2020 International Conference Management of Technology - Step to Sustainable Production, which will take place from $30^{\text {th }}$ September $-2^{\text {nd }}$ October 2020 in Bol, island Brač (Croatia). The paper will not be published anywhere else.

\section{REFERENCES}

[1] Göller, F. \& Guffarth, D. (2017). Der Automotive Aftersales im Wandel. Retrieved from: https://docplayer.org/ 68481677-Der-automotive-aftersales-im-wandel-heraus forderungen-und-auswirkungen-auf-das-servicegeschaeft-deroem.html, (2020).

[2] Bauer, W., Riedel, O., Hermann, F., Borrmann, D., \& Sachs, C. (2018). Wirkungen der Fahrzeugelektrifizierung auf die Beschäftigung am Standort Deutschland. Retrieved from: http://publica.fraunhofer.de/dokumente/N-520883.html, (2020).

[3] Karle, A. (2017). Elektromobilität. Grundlagen und Praxis. München, Carl Hanser Verlag. https://doi.org/10.3139/9783446451131

[4] Röbken, H. \& Wetzel, K. (2016). Quantitative und Qualitative Forschungsmethoden. Retrieved from: https://uol.de/ fileadmin/user_upload/c31/Studiengaenge/BABusinessAdmin/ Download/Leseproben/bba_leseprobe_quli_quanti_forschung smethoden.pdf, (2020).

[5] Nieder, T. \& Püttner, A. (2020). Datenservice Erneuerbare Energien. Bestand an Elektro-Pkw weltweit. Retrieved from: https://www.zsw-bw.de/mediathek/daten service.html\#c6700, (2020).

[6] Verband der Automobilindustrie e.V. (2018): Jahresbericht 2018. Die Automobilindustrie in Daten und Fakten. Retrieved from: https:/www.vda.de/de/services/Publikationen/jahres bericht-2018.html, (2020).

[7] Oehler, S. (2018). Emissionsfreie Gebäude. Das Konzept der "Ganzheitlichen Sanierung" für die Gebäude der Zukunft. Wiesbaden: Springer Vieweg. https://doi.org/10.1007/978-3-658-16056-2

[8] Thomes, P. (2018). Elektromobilität. Eine historisch basierte Analyse, in: Kampker, A., Valee, D., \& Schnettler, A. Elektromobilität. Grundlagen einer Zukunftstechnologie. Berlin Heidelberg: Springer-Verlag, 5-13.

[9] Tschöke, H., Raum, M., Kümmel, S., \& Kowal, J. (2015). Elektrifizierte Antriebssysteme mit Verbrennungsmotoren, in: Tschöke, Helmut: Die Elektrifizierung des Antriebsstranges: Basiswissen. Wiesbaden: Springer, 2-16. https://doi.org/10.1007/978-3-658-04644-6_1

[10] Saenger-Zetina, S. \& Wagner, M. (2012). Hybride Antriebsstrukturen, in: Reif, K., Noreikat, K. E., \& Borgeest, K. Kraftfahrzeug-Hybridantriebe: Grundlagen, Komponenten, Systeme, Anwendungen. Wiesbaden: Springer Vieweg, 7-68. https://doi.org/10.1007/978-3-8348-2050-1_2 
[11] Lowry, J. \& Larminie, J. (2012). Electric Vehicle Technology Explained, West Sussex: Wiley. https://doi.org/10.1002/9781118361146

[12] Kasper, R. (2015). Elektrische Fahrantriebe, in: Tschöke, Helmut: Die Elektrifizierung des Antriebsstranges Basiswissen. Wiesbaden: Springer Vieweg, p. 39.

[13] Schaloske, M. C. (2020). Brennstoffzellentechnologie. Retrieved from: https://www.e-mobilbw.de/themen/brennstoff zellentechnologie, (2020).

[14] Gicklhorn, K. (2020). Elektromobilität. Retrieved from: https://www.e-mobilbw.de/themen/elektromobilitaet\#\&gid= lightbox-group-507\&pid=0, (2020).

[15] Diez, W., Reindl, S., \& Brachat, H. (2005): Grundlagen der Automobilwirtschaft. München: Auto Business Verlag.

[16] Erste Bank Oesterreich (2017). Studie: Die österreichische Automobilwirtschaft in Zahlen. Retrieved from: https://newsroom.sparkasse.at/2017/09/08/studie-dieoesterreichische-automobilwirtschaft-in-zahlen/50962, (2020).

[17] Pflaum, D. (2007). Die Kommunikationspolitik im After Sales Service, in: Pepels, W. After Sales Service: Geschäftsbeziehungen profitabel gestalten. Düsseldorf: Symposion Publishing GmbH, p. 191.

[18] Göller, F. \& Guffarth, D. (2017). Der Automotive Aftersales im Wandel. Retrieved from: https://www.horvathpartners.com/fileadmin/horvath-partners.com/assets/05 Media_Center/PDFs/deutsch/WP_Automotive_Aftersales_we b_g.pdf, (2020).

[19] Hättih, H. (2009). Markenloyalität im Aftersales-Marketing. München/Mering: Rainer Hampp Verlag.

[20] Wyman, O. (2015). Systemprofi 2035: Autohersteller müssen den Vertrieb neu erfinden. Retrieved from: https:/www.presseportal.de/download/document/336925oliverwyman-grafiken-systemprofit2035-vertrieb-neuerfinden-final-08092015.pdf, (2020).

[21] Wolf, G. (2019). Kfz-Wirtschaft mit Detailberichten: Fahrzeughandel, Kfz-Werkstätten, Tankstellen. Retrieved from: https://www.bankaustria.at/files/Kfz-Wirtschaft.pdf, (2020).

[22] Dispan, J. (2017). Branchenanalyse Kraftfahrzeug-Gewerbe. Düsseldorf: Hans-Böckler-Stiftung.

[23] Verein für Konsumenteninformation (2012). Kfz-Garantie: freie Werkstätten. Treue lohnt nicht. Retrieved from: https://www.konsument.at/cs/Satellite?c=Magazin Artikel\&cid $=318881692355$ \&pagename $=$ Konsument $\% 2 \mathrm{FMa}$ gazinArtikel\%2FprintMagazinArtikel, (2020).

[24] Kords, M. (2020). Anzahl der Neuzulassungen von Elektroautos in Österreich von 2008 bis 2019. Retrieved from: https://de.statista.com/statistik/daten/studie/285808/umfrage/n euzulassungen-von-elektroautos-in-oesterreich/, (2020).

[25] Kords, M. (2020). Anzahl der Kfz-Neuzulassungen in Österreich von 1992 bis 2019. Retrieved from: https:/de.statista.com/statistik/daten/studie/718009/umfrage/k fz-absatz-in-oesterreich/, (2020).

[26] Tennstedt, F., Elsässer, S., Betke, R., \& Gebauer, H. (2010): The Aftermarket in the Automotive Industry - How to Optimize Aftermarket Performance in Established and Emerging Markets. Retrieved from: https://www.capgemini.com/wp-content/uploads/2017/07/tl The_Aftermarket_in_the_Automotive_Industry.pdf, (2020).

[27] Adams, P., Gaydoul, R., \& Kathan, D. (2015). Kfz-Werkstätten der Zukunft - mit neuem Selbstverständnis ins digitale Zeitalter. Retrieved from: https://www.horvath-partners.com/ fileadmin/horvath-partners.com/assets/05_Media_Center/ PDFs/deutsch/Werkstatt Zukunft web-g.pdf, (2019).
[28] Wienkötter, M. (2019). Die Batterie: Ausgeklügeltes Thermomanagement, 800 Volt Systemspannung. Retrieved from: https://newsroom.porsche.com/de/produkte/taycan/ batterie-18541.html, (2020).

[29] Österreichischer Verband für Elektrotechnik (2015). OVERichtlinie R19:2015-06-01. Retrieved from: https://www.ove.at/shop/de/product/ove-richtlinie-r-19-201506-01, (2020).

[30] Österreichischer Verband für Elektrotechnik (2017). OVERichtlinieR16:2017-12-01. Retrieved from: https://www.ove.at/shop/de/product/ove-richtlinie-r-16-201712-01, (2020).

[31] Katzinger, B. (2019). Wer dableiben will muss investieren. Auto \& Wirtschaft, April 2019, 14-15.

[32] Diez, W., Schreier, N., \& Haag, A. (2014). Entwicklung der Beschäftigung im After Sales - Effekte aus der Elektromobilität. Retrieved from: https:/www.e-mobilbw.de/ files/e-mobil/content/DE/Publikationen/PDF/ After-SalesStudie_RZ_Web.pdf, (2020).

[33] Baeuchle, $\bar{C}$. (2016). Erfolg in der Werkstatt mit den richtigen Abläufen. Retrieved from: https:/www.kfz-betrieb.vogel.de/ erfolg-in-der-werkstatt-mit-den-richtigen-ablaeufen-a545033/, (2020).

[34] Grawunder, N. \& Liskowsky, V. (2013). Betrieb und Instandhaltung von Kraftfahrzeugen, in: Braess, HansHermann; Seiffert, Ulrich: Vieweg Handbuch Kraftfahrzeugtechnik, Wiesbaden, Springer Vieweg, 12021204.

[35] Weidenbach, M., Sadoun, J., \& Pölz, P. (2019). Future of Sales and Aftersales. Retrieved from: https://www2.deloitte.com/de/ de/pages/consumer-industrial-products/articles/future-ofautomotive-sales-and-aftersales-de.html, (2020).

[36] Sandberg, B. (2013). Wissenschaftlich Arbeiten von Abbildung bis Zitat. Lehr- und Übungsbuch für Bachelor, Master und Promotion. München: Oldenbourg Verlag. https://doi.org/10.1524/9783486778526

[37] Gläser, J. \& Laudel, G. (2009). Experteninterviews und qualitative Inhaltsanalyse als Instrumente rekonstruierender Untersuchungen. Wiesbaden: VS Verlag für Sozialwissenschaften / GWV Fachverlage GmbH. https://doi.org/10.1007/978-3-531-91538-8_4

\author{
Authors' contacts: \\ Helmut Ropin, MSc. in Eng. \\ (Corresponding author) \\ Industrial Management, FH JOANNEUM, \\ Werk-VI-Straße 46, Kapfenberg, A-8605, Austria \\ +43 316 5453-8338, helmut.ropin@fh-joanneum.at
}

Robert Supan, BSc. in Eng.

Industrial Management, FH JOANNEUM,

Werk-VI-Straße 46, Kapfenberg, A-8605, Austria

+43 316 5453-6304, robert.supan2@fh-joanneum.at 